\title{
High aluminum availability may affect Styrax camporum, an Al non-accumulating species from the Brazilian savanna
}

\author{
Otávia F. A. A. Banhos • Marcelo Claro de Souza • \\ Gustavo Habermann
}

Received: 30 November 2015/Accepted: 23 December 2015/Published online: 25 January 2016

(C) Brazilian Society of Plant Physiology 2016

\begin{abstract}
In the Cerrado vegetation, generally known as 'Brazilian savanna', aluminum ( $\mathrm{Al})$ accumulating and non-accumulating plants coexist, growing on soils that are acidic, poor in nutrients and rich in Al. Differing from Al-sensitive species, these plants are not expected to experience $\mathrm{Al}$ injuries. Using Styrax camporum, a non-accumulating plant, we recorded biometric variations in leaves, shoots and roots of young plants exposed to 0 and $1480 \mu \mathrm{M} \mathrm{Al}$ in a nutrient solution. Photosynthetic responses were measured bi-weekly over 91 days. Plants exposed to $\mathrm{Al}$ drastically reduced flushing, indicating that $\mathrm{Al}$ interferes with the functioning of the shoot apex. Aluminum caused low $\mathrm{CO}_{2}$ assimilation rate, largely explained by
\end{abstract}

O. F. A. A. Banhos

Departamento de Botânica, Instituto de Biociências, Programa de Pós-Graduação em Ciências Biológicas (Biologia Vegetal), Univ Estadual Paulista, Unesp, Av. 24-A, 1515, Rio Claro, SP 13506-900, Brazil

M. C. de Souza

Departamento de Ciências Farmacêuticas, Faculdade de Ciências Farmacêuticas de Ribeirão Preto, Universidade de São Paulo, Usp, Av. do Café, s/n, Ribeirão Preto, SP 14040-903, Brazil

G. Habermann ( $₫)$

Departamento de Botânica, Instituto de Biociências, Univ Estadual Paulista, Unesp, Av. 24-A, 1515, Rio Claro, SP 13506-900, Brazil e-mail: ghaber@rc.unesp.br low stomatal conductance, while Al-induced decrease in photochemical performance occurred only on some dates during the experiment. In addition, the absorbed Al was mostly retained in the roots. Although counterintuitive, as this species grows on Al-rich soils, we noted that high $\mathrm{Al}$ availability impairs lateral root formation, causing an impact on water uptake and gas exchange rates of this species.

Keywords $\mathrm{Al}^{3+}$. Cerrado woody species . Metal toxicity $\cdot$ Nutrient solution $\cdot$ Photosynthesis . Styracaceae

\section{Introduction}

The flora of the Cerrado is comprised of aluminum (Al) accumulating and non-accumulating species (Haridasan 1982; Souza et al. 2015a), which are distributed between savanna-type (cerrado sensu stricto) and forest (Cerradão) physiognomies of this vegetation (Ratter et al. 1997). These physiognomies are mostly comprised of shrubs and trees that grow on dystrophic and acidic $(\mathrm{pH}<4.0)$ soils with exchangeable Al saturation ( $\mathrm{m} \%$ ) between 60 and $90 \%$ (Ratter et al. 1997; Habermann and Bressan 2011, Souza et al. 2015b). In addition, these soils are limited in nutrients, mainly to $\mathrm{P}, \mathrm{Zn}, \mathrm{Cu}$, and $\mathrm{Mn}$ (Haridasan and Araujo 1988; Haridasan 2008; Pivello et al. 2010).

Some Al-accumulating plants may show above $15,000 \mathrm{mg} \mathrm{Al} \mathrm{kg}^{-1}$ dry leaves and these species 
belong to a few families occurring in the Cerrado: Melastomataceae (Miconia spp), Rubiaceae (Palicourea rigida), Vochysiaceae (Callisthene sp., Qualea spp, Salvertia convallariodora and Vochysia sp) and Loranthaceae (Passovia ovata and Psittacanthus robustus) (Haridasan 1982; Haridasan and Araujo 1988; Andrade et al. 2011; Scalon et al. 2013). Alaccumulating species may constitute $35 \%$ of the species found in a Cerrado sensu stricto remnant (Haridasan 1982), and $18 \%$ of the species found in a Cerradão fragment (Haridasan and Araujo 1988). The rest of the non-herbaceous Cerrado plant community may be considered non-accumulating species, which show between 100 and $600 \mathrm{mg} \mathrm{Al} \mathrm{kg}{ }^{-1}$ dry leaves (Haridasan 1982; Souza et al. 2015a).

On the other hand, most Al-sensitive species are herbaceous (crop) plants (Silva et al. 2012) or trees that are not able to secrete Al-organic acid complexes at the root tip (Brunner and Sperisen 2013). In these sensitive species, the most conspicuous symptom is the inhibition of root growth (Horst et al. 2010; Sun et al. 2010) because the $\mathrm{Al}$ binds itself to the rhizodermis, increasing its rigidity while reducing the ability of outer cells to elongate (Kopittke et al. 2008). These plants also show reduced gas exchange rates, such as $\mathrm{CO}_{2}$ assimilation rate $(A)$, which could be considered an indirect/long-distance effect caused by the fact that toxic Al binds itself to root cell walls and can be permanently stored in this organ (Vitorello et al. 2005; Rangel et al. 2009). Sensitive plants exposed to $\mathrm{Al}$ accumulate $70-80 \%$ more $\mathrm{Al}$ in roots than in leaves and shoots (Jiang et al. 2009; Yang et al. 2011). Some studies attribute Al-induced decrease in $A$ to photochemical apparatus injuries, as evidenced by low values of electron transport rate (ETR), effective quantum yield of photosystem II (ФPSII) and photochemical quenching (qP) in plants exposed to more than $1000 \mu \mathrm{M} \mathrm{Al}$ (Chen et al. 2005; Jiang et al. 2008; 2009).

As far as we are aware, there are no studies of $\mathrm{Al}$ effects on plant growth or photosynthetic performance in either Al-accumulating or Al-non-accumulating species from the Cerrado. Aluminum has also been suggested to have some unknown positive roles in chloroplasts of $\mathrm{Al}$-accumulating species, as it has been histochemically evidenced in these organelles of $Q$. grandiflora and Callisthene major (Vochysiaceae) (Andrade et al. 2011). Moreover, some Al-accumulating species do not grow well and show leaf chlorosis when cultivated in eutrophic soils with low $\mathrm{m} \%$ (Haridasan 2008). In this way, although no physiological role has been suggested for $\mathrm{Al}$ in these plants, accumulating and non-accumulating species coexist in the Cerrado, growing on acidic soils with m $\%>70 \%$, with no apparent damage to their organs or metabolism (Andrade et al. 2011). Therefore, $\mathrm{Al}$ is not expected to cause disturbances in growth, physiological responses or morphological changes in these plants.

Styrax camporum Pohl. (Styracaceae) is considered a non-accumulating species (Haridasan 1982), although we have observed between 1000 and $1500 \mathrm{mg} \mathrm{Al} \mathrm{kg}^{-1}$ dry leaves in field studies (data not shown). It is a tree (3-8 $\mathrm{m}$ in height), naturally occurring in Cerrado areas, and it exhibits a wide distribution between Cerrado physiognomies (Kissmann et al. 2012). It has been observed in remnants of Cerradão, cerrado sensu stricto, and other forestinfluenced environments within Cerrado areas (Nakajima and Monteiro 1987). Its seeds are dispersed during the dry season (April-August) and are relatively easy to germinate (Kissmann and Habermann 2013), growing into five-leaf plants within approximately eight months.

In the present study, we predicted that $S$. camporum plants are not sensitive to high soluble Al concentration $(>1000 \mu \mathrm{M})$ in nutrient solution. We recorded biometrical variations of leaves, shoots and roots of plants exposed to $\mathrm{Al}$ over 91 days and the $\mathrm{Al}$ concentration in these organs at the end of the study. During this period, we also measured photosynthetic parameters, such as gas exchange rates, as well as photochemical performances.

\section{Materials and methods}

\subsection{Plant material and experimental conditions}

Mature fruits of Styrax camporum Pohl were collected from adult trees growing in a Cerradão area (37 ha; $22^{\circ} 15^{\prime} \mathrm{S}$ and $47^{\circ} 00^{\prime} \mathrm{W}$ ) in the municipality of Corumbataí, state of São Paulo, southeastern Brazil. Fifteen eight-month-old plants ( $26 \pm 1 \mathrm{~cm}$ in height) were obtained from seeds that germinated in May 2013. The roots of these plants were rinsed under tap water to remove substrate debris composed of organic substrate (Tropstrato florestal ${ }^{\circledR}$, São Paulo, Brazil), sand and 
oxisol (1:1:1; v:v:v), on which these plants grew in $2 \mathrm{~L}$ (black) plastic bags, inside a greenhouse. The intact plants were transferred to opaque plastic boxes $(50 \mathrm{~cm}$ in length $\times 30 \mathrm{~cm}$ in width $\times 15 \mathrm{~cm}$ in height; $20 \mathrm{~L}$ ), containing nutrient solutions with 0 and $1480 \mu \mathrm{M}$ Al.

As far as we can tell, studies of young nonaccumulating plants from the Cerrado under contrasting $\mathrm{Al}$ concentrations are not available, and we have not previously tested other Al concentrations for $S$. camporum. Therefore, we chose $1480 \mu \mathrm{M} \mathrm{Al}$ (40 mg $\mathrm{L}^{-1}$ ) because most studies testing high [Al] on Alsensitive plants have used more than $1000 \mu \mathrm{M}$ : $1480 \mu \mathrm{M}$ (Konrad et al. 2005; Coffea arabica), $2000 \mu \mathrm{M}$ (Chen et al. 2005; Citrus reshni), $1600 \mu \mathrm{M}$ (Jiang et al. 2008; C. grandis), $1200 \mu \mathrm{M}$ (Jiang et al. 2009; C. grandis) and $1850 \mu \mathrm{M}$ (Silva et al. 2012; Secale cereale).

We used a nutrient solution (Furlani and Furlani 1988) with a chemical composition based on Clark's solution (Clark 1975) that has been used to study Al toxicity in Al-sensitive tree species (Santos et al. 2000). However, we diluted its macro- and micronutrient concentrations by seven in order to resemble the nutrient composition of Cerrado soils (Habermann and Bressan 2011; Souza et al. 2015b). For example, Kopittke et al. (2010) also observed that the soil solution from an Australian acidic oxisol exhibits nutrient concentrations that are approximately seven-fold lower than those in Hoagland \& Arnon's nutrient solution. Although nutrient concentrations in solutions (mass per liquid volume) cannot be compared with nutrient exchangeable contents measured in soils (ionic charges per volume of a solid matrix), we observed that this final nutrient solution showed no precipitation and induced no nutrient deficiency in $S$. camporum plants. The $\mathrm{pH}$ of the aerated solution was maintained at $4.0 \pm 0.1$. Nominal $1480 \mu \mathrm{M} \quad \mathrm{Al}$ supply resulted in $1100 \pm 5.3 \mu \mathrm{M} \mathrm{Al}$, and nutrient concentrations were as follows. Macronutrients (in $\mathrm{mM}$ ): $\mathrm{NO}_{3}{ }^{-} 0.137 ; \mathrm{NH}_{4}{ }^{+}$ 0.058; P, 0.0019; K, 0.123; Ca, 0.204; Mg, 0.047; S, 0.031. Micronutrients (in $\mu \mathrm{M}$ ): $\mathrm{Cl}, 30.58$; Fe (EDTA), 3.32; B, 1.19; Mn, 0.41; Zn, 0.10; Cu, 0.04; Mo, 0.04. In addition, when we tested the chemical composition of this solution on Geochem-EZ software (Shaff et al. 2010) it resulted in more than $85 \%$ free $\mathrm{Al}^{3+}$ available. Solution $\mathrm{pH}$ was monitored daily (corrected to 4.0, if necessary) and replaced every 10 days.

The boxes stood on benches inside a greenhouse with semi-controlled conditions. During the experiment, the photosynthetic photon flux density (PPFD) inside the greenhouse was $782.03 \pm 157.73 \mu \mathrm{mol}$ photons $\mathrm{m}^{-2}$ $\mathrm{s}^{-1}$, with photoperiod of approximately $13 \mathrm{~h}$, and air temperature, $29.5 \pm 1.9$. Expanded polystyrene (Isopor $\left.^{(B)}\right) 50 \times 30 \mathrm{~cm}$ plates $(2-\mathrm{cm}$ thick) with five holes $(2.5 \mathrm{~cm}$ in diameter) were floated on the nutrient solution in the boxes, and the plants were fixed in these holes with polyurethane foam strips that were placed around the plant collar.

\subsection{Experimental design}

Five plants were grown in the box with the nutrient solution containing $1480 \mu \mathrm{M} \mathrm{Al}$, and five plants were grown in the box with the solution containing $0 \mu \mathrm{M}$ Al. In addition, leaves of five plants were counted and their shoot and root lengths $(\mathrm{cm})$, leaf area $\left(\mathrm{cm}^{2}\right)$ and biomasses of leaves, stems and roots were determined at the beginning of the study. After 91 days, these biometric parameters were thoroughly measured for plants from both boxes, and the $\mathrm{Al}$ concentration was also measured in roots, shoots and leaves.

At 0 (on the day of planting), 14, 21, 28, 42, 49, 56, $62,70,86$ and 91 days after planting (DAP), the gas exchange and chlorophyll fluorescence were measured on the plants' leaves.

\subsection{Photosynthetic parameters}

$\mathrm{CO}_{2}$ assimilation $(A)$ and transpiration $(E)$ rates, stomatal conductance $\left(g_{s}\right)$ and intercellular $\mathrm{CO}_{2}\left(C_{i}\right)$ were measured with an open gas exchange system (LI6400xt; LI-COR, Lincoln, NE, USA). Water use efficiency (WUE) was calculated as $A / E$, according to Habermann et al. 2003. $\mathrm{CO}_{2}$ concentration entering the leaf cuvette was $390 \mu \mathrm{mol} \mathrm{CO} \mathrm{mol}^{-1}$ air, as provided by the $6400-01 \mathrm{CO}_{2}$ mixer (LI-COR). Measurements were performed between 9:00 and 11:00 am (Feistler and Habermann 2012) on cloudless sky days, under natural fluctuation of air temperature and vapor pressure deficit (VPD) inside the greenhouse. The VPD inside the leaf cuvette was $1.5 \pm 0.2 \mathrm{kPa}$, which means that the relative humidity in the (reference) chamber oscillated around $65 \%$. Photosynthetic photon flux density (PPFD) was supplied by an artificial LED light (10\% blue and $90 \%$ red) source (6400-40 LCF, LI-COR), which was set to provide $1200 \mu \mathrm{mol}$ photons $\mathrm{m}^{-2} \mathrm{~s}^{-1}$, as this value saturates $A$ in $S$. camporum leaves (Habermann et al. 2011). 
Chlorophyll $a$ fluorescence was measured with a portable modulated fluorometer (6400-40 LCF; LICOR), which was integrated into the LI-6400xt gas exchange system. For calculating maximum quantum yield of photosystem II (PSII) $\left(\mathrm{F}_{\mathrm{v}} / \mathrm{F}_{\mathrm{m}}\right)$, leaves were dark-adapted for 30 min (Bolhàr-Nordenkampf and Öquist 1993) with aluminum foils, before measuring the fluorescence. The saturating light pulse was $7000 \mu \mathrm{mol}$ photons $\mathrm{m}^{-2} \mathrm{~s}^{-1}$ during $0.7 \mathrm{~s} . \mathrm{F}_{\mathrm{m}}$ and $\mathrm{F}_{\mathrm{v}}$ are maximum and variable fluorescence in darkadapted leaves, respectively. The effective quantum yield of PSII $\left(\Phi_{\mathrm{PSII}}\right)$, was calculated as $\left(\mathrm{F}_{\mathrm{m}}{ }^{\prime}-\mathrm{F}_{\mathrm{s}}\right) / \mathrm{F}_{\mathrm{m}}$, , where $F_{m}$ ' and $F_{s}$ indicate the maximum and the steady state fluorescence in light-adapted leaves, respectively. Apparent electron transport rate $\left(\mathrm{ETR}=\Phi_{\mathrm{PSII}} \mathrm{PPFD}\right.$ 0.50 .85 ) was calculated, using 0.5 as the fraction of excitation energy distributed to PSII, and 0.85 as the fractional light absorbance. The proportion of open PSII reactions centers $(\mathrm{qP})$ was measured as $\left(\mathrm{F}_{\mathrm{m}}{ }^{\prime}-\mathrm{F}_{\mathrm{s}}\right) /$ $\left(\mathrm{F}_{\mathrm{m}}{ }^{\prime}-\mathrm{F}_{\mathrm{o}}{ }^{\prime}\right)$ (Bolhàr-Nordenkampf and Öquist, 1993). We also calculated the light fraction used for PSII in photochemistry $\left[\mathrm{P}=\left(\left(\mathrm{F}_{\mathrm{m}}{ }^{\prime}-\mathrm{F}_{\mathrm{s}}\right) / \mathrm{F}_{\mathrm{m}}{ }^{\prime}\right)\right]$, heat dissipation in the antenna $\left[\mathrm{D}=1-\left(\mathrm{F}_{\mathrm{v}}{ }^{\prime} / \mathrm{F}_{\mathrm{m}}{ }^{\prime}\right)\right]$ and heat dissipation in reaction centers $\left[\mathrm{E}=(1-\mathrm{qP})\left(\mathrm{F}_{\mathrm{v}}{ }^{\prime} /\right.\right.$ $\left.\left.\mathrm{F}_{\mathrm{m}}{ }^{\prime}\right)\right]$, which were in accordance to Demming-Adams (1996). For these calculations, $F_{v}$ ' is the variable fluorescence between the maximal $\left(\mathrm{F}_{\mathrm{m}}{ }^{\prime}\right)$ and minimal $\left(\mathrm{F}_{\mathrm{o}}{ }^{\prime}\right)$ fluorescence from light-adapted leaves.

\subsection{Biometric parameters}

Lengths of stems (from plant collar to the shoot apex) and roots (from plant collar to the root tip) were measured with a ruler $(\mathrm{cm})$ and the number of leaves, counted.

The leaves, stems (plus petioles) and roots of the plants were separated. Leaf area $\left(\mathrm{cm}^{2}\right)$ was measured with an area meter (LI-3100C, LI-COR). Leaf, stem and root samples were oven-dried at $60{ }^{\circ} \mathrm{C}$ to constant mass, and biomass of these organs as well as the total biomass were measured using analytical scale.

\subsection{Aluminum concentration in roots, shoots and leaves}

At 91 DAP, after measuring the biomass of plant organs, the samples were oven dried at $60{ }^{\circ} \mathrm{C}$ for $72 \mathrm{~h}$, ground and digested in a solution of sulfuric:nitric:percloric acids (1:10:2, v/v/v). After digestion, Al concentrations were determined by using an atomic absorption spectrophotometer (Sarruge and Haag 1974) and were expressed as mg Al per kg dry plant material.

\subsection{Data analysis}

The variation of $A, g_{s}, E, C_{i}, A / E, \mathrm{~F}_{\mathrm{v}} / \mathrm{F}_{\mathrm{m}}$, ФPSII, ETR, qP, P, D, and E between both treatments were analyzed using a $\mathrm{T}$ test at $5 \%$ level at every evaluation date (0-91 DAP). We used the same T-test at $5 \%$ level to check the variation of the number of leaves, leaf area, shoot and root lengths, and biomass of leaf, shoot, root and total biomass between both treatments at 0 and 91 DAP and, for these same biometrical traits, between 0 and 91 DAP for each treatment individually. For leaf, shoot, root and total $\mathrm{Al}$ concentrations measured at 91 DAP, the same T-test at $5 \%$ level was used to check for differences between both treatments.

We used an allometric bivariate analysis (standard major axis regression-SMA) to test the correlation between $A \times g_{s}$ and $E \times g_{s}$ for both treatments and the variations in slope and intercept between the treatments. Data were $\log _{10}$ transformed (Warton et al. 2006, 2012). Statistical procedures were performed in R software (R Development Core Team 2012).

\section{Results}

Aluminum affected roots more than stems and leaves because, in plants exposed to $\mathrm{Al}$, leaves were green, fully developed and had the same shape as those from plants not exposed to Al (Fig. 1a, b). Roots, however, were visually affected by $\mathrm{Al}$, as there was a lack of lateral (or fine) roots in plants exposed to $1480 \mu \mathrm{M} \mathrm{Al}$, which appeared to invest more in coarse roots (Fig. 1d) in relation to plants not exposed to $\mathrm{Al}$ (Fig. 1c).

Plants exposed to $\mathrm{Al}$ did not sprout normally, as their average number of leaves was $55 \%$ lower than the control plants at $91 \mathrm{DAP}$, and plants exposed to $\mathrm{Al}$ did not increase the number of leaves from 0 to 91 DAP (Fig. 2a). Consequently, the leaf area of plants exposed to Al was the same between 0 and 91 DAP (Fig. 2b). In addition, the leaf biomass was similar between both treatments at 91 DAP, but while the control plants exhibited a four-fold increase in leaf 
Fig. 1 Morphological details of shoots and leaves $(\mathbf{a}, \mathbf{b})$ and roots $(\mathbf{c}, \mathbf{d})$ of $S$. camporum plants grown for 91 days in nutrient solutions containing $0(\mathbf{a}, \mathbf{c})$ and 1480 (b, d) $\mu \mathrm{M} \mathrm{Al}$

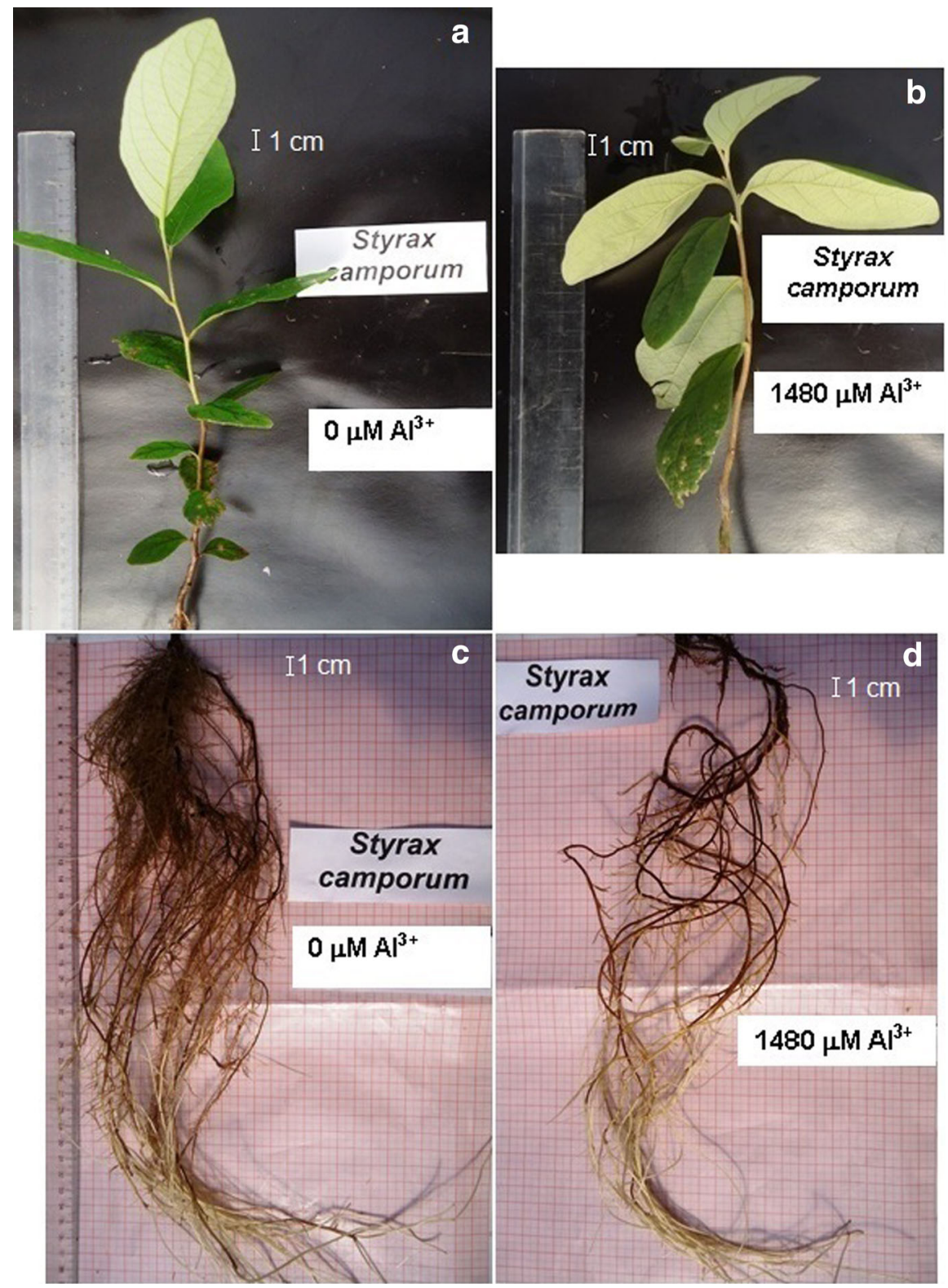

biomass, plants exposed to $\mathrm{Al}$ showed an insignificant rise in this parameter between 0 and 91 DAP (Fig. 3a).

Aluminum also affected shoot growth because plants exposed to $\mathrm{Al}$ maintained the same shoot length after 91 days, while the shoot length of plants not exposed to $\mathrm{Al}$ increased $20 \%$ during the same period (Fig. 2c). Although both treatments showed significant increases in their shoot biomasses from 0 to 91 DAP, plants not exposed to Al had a sharp five-fold increase in shoot biomass during the same period, but the shoot biomass, when comparing both treatments, was the same at 91 DAP (Fig. 3b).

The root length, when comparing both treatments, was the same at $91 \mathrm{DAP}$, but the roots of plants exposed to $\mathrm{Al}$ were $10 \mathrm{~cm}$ shorter than those from the control plants (Fig. 2d). Both treatments showed significant increase in their root biomasses from 0 to 91 DAP. In plants exposed to $\mathrm{Al}$ this parameter showed a ten-fold increase, while those not exposed to $\mathrm{Al}$ had a 16-times increase in root biomass during the same period (Fig. 3c). 


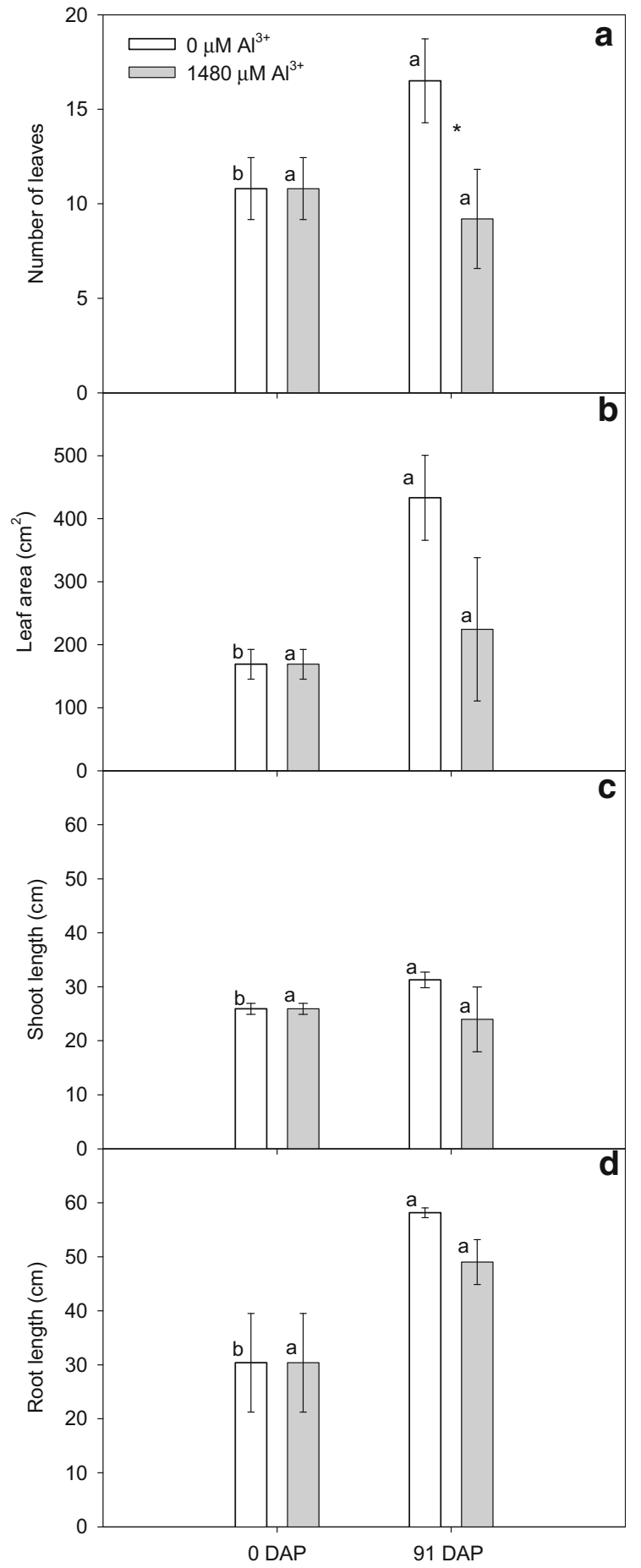

Fig. 2 Mean values ( $n=5$ plants) of biometric parameters (ad) of $S$. camporum plants at 0 and 91 days after planting (DAP) in nutrient solutions containing 0 and $1480 \mu \mathrm{M}$ Al. For the same treatment, distinct letters indicate significant differences $(\mathrm{P}<0.05)$ between 0 and 91 DAP. Asterisks indicate significant difference $(\mathrm{P}<0.05)$ between treatments at 91 DAP (vertical bars $=$ s.d.)

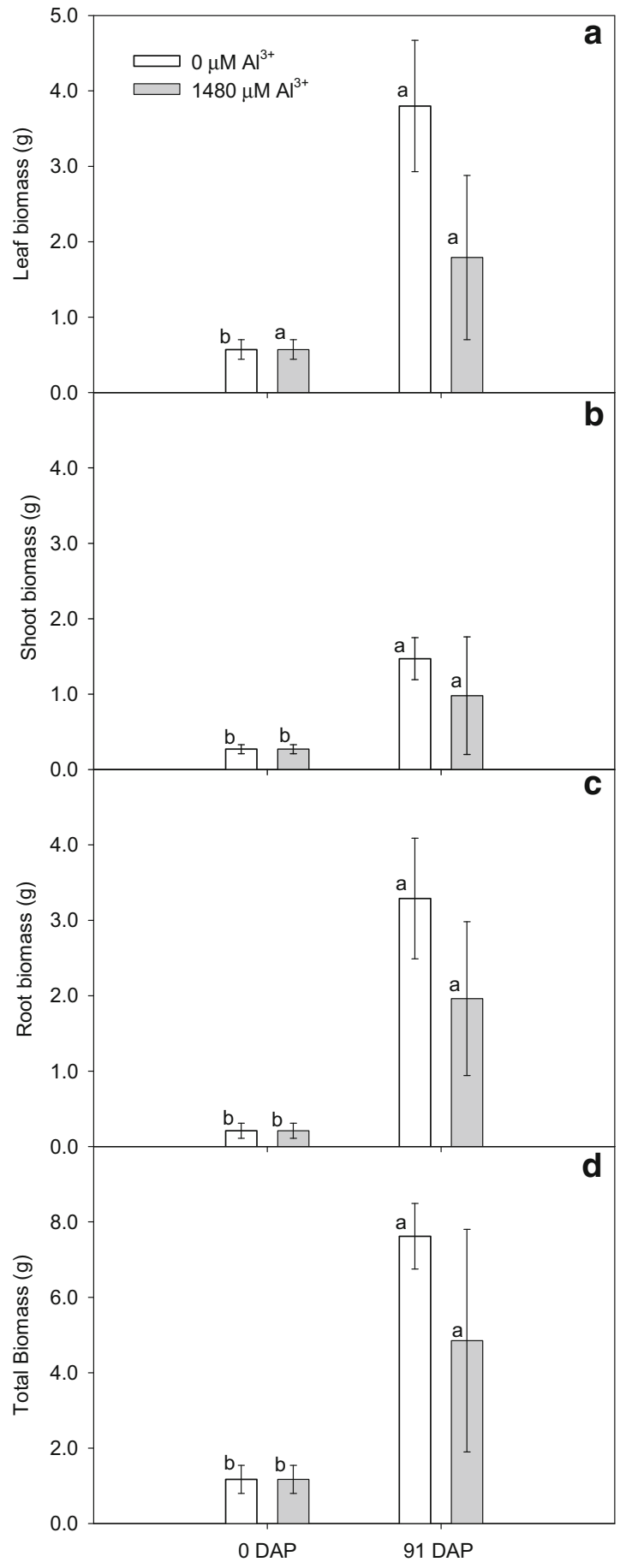

Fig. 3 Mean values ( $\mathrm{n}=5$ plants) of biomass of organs (ac) and total plant biomass (d) of $S$. camporum plants at 0 and 91 days after planting (DAP) in nutrient solutions containing 0 and $1480 \mu \mathrm{M}$ Al. For the same treatment, distinct letters indicate significant differences $(\mathrm{P}<0.05)$ between 0 and 91 DAP. Absence of asterisks indicates non-significant difference $(\mathrm{P}>0.05)$ between treatments at $91 \mathrm{DAP}($ vertical bars $=$ s.d. $)$ 
Fig. 4 Mean values ( $\mathrm{n}=5$ plants) of gas exchange rates $(\mathbf{a}, \mathbf{b}$, c), intercellular $\mathrm{CO}_{2}(\mathbf{d})$, and water use efficiency (e) of $S$. camporum plants grown for 91 days in nutrient solutions containing 0 and $1480 \mu \mathrm{M} \mathrm{Al}$. Asterisks indicate significant difference $(\mathrm{P}<0.05)$ between treatments at each evaluation date. (vertical bars $=$ s.d.)

Aluminum reduced gas exchange rates. Despite the variability observed for these rates, $A$ was lower in plants exposed to $\mathrm{Al}$ when compared to those not exposed to $\mathrm{Al}$ from 14 until 91 DAP (Fig. 4a). Values of $g_{s}$ and $E$ also reflected the response pattern observed for $A$. Except for the beginning and the end of the study, $g_{s}$ and $E$ remained lower in plants exposed to $\mathrm{Al}$ when compared to those not exposed to $\mathrm{Al}$ (Fig. 4b, c). Aluminum did not considerably affect the intercellular $\mathrm{CO}_{2}\left(C_{i}\right)$, except at 21, 62 and 86 DAP when $C_{i}$ was higher in plants not exposed to $\mathrm{Al}$ in relation to those cultivated with Al (Fig. 4d). Similarly, although not considerably affected by $\mathrm{Al}$, the water use efficiency $(A / E)$ was higher at 21,62 and $86 \mathrm{DAP}$ in plants exposed to $\mathrm{Al}$ when compared to those not exposed to Al (Fig. 4e). In addition, we observed significant correlations between $A \times g_{s}$ and $E \times g_{s}$ for both treatments (Fig. 5a, b). Both correlations differed for intercepts between treatments $(\mathrm{p}<0.05)$.

Aluminum did not affect $F_{v} / F_{m}$ (Fig. 6a). However, $\mathrm{Al}$ caused reductions in ФPSII (Fig. 6b) and ETR (Fig. 6c), mainly between 14 and 56 DAP. Photochemical quenching was reduced in plants exposed to $\mathrm{Al}$, but only at 14 and 21 DAP (Fig. 6d), and fractions of absorbed light used in photochemistry $(\mathrm{P})$ were lower in plants exposed to $\mathrm{Al}$ at the beginning of the study and at 42 and 49 DAP (Fig. 7b). The heat dissipation in the antennas (D) was increased in plants exposed to $\mathrm{Al}$ at 21 (+3.5\%), $28(+14 \%), 49(+27.5 \%), 62(+12 \%), 86$ $(+13.8 \%)$ and $91(+13.7 \%)$ DAP, while heat dissipation in the reaction centers (E) was higher in plants exposed to $\mathrm{Al}$ only at $21 \mathrm{DAP}(+9.6 \%)$ (Fig. 7).

At the end of the study, the plants exposed to $\mathrm{Al}$ showed higher $\mathrm{Al}$ concentration in relation to plants not exposed to $\mathrm{Al}$, and this was a reflection of higher Al concentration found in all plant organs (Fig. 8). Interestingly, in plants exposed to $\mathrm{Al}, 69.5 \pm 1.9 \%$ of it was retained in the roots, while only $23.2 \pm 3.4 \%$ and $7.1 \pm 1.9 \%$ were retained in the shoots and leaves, respectively.

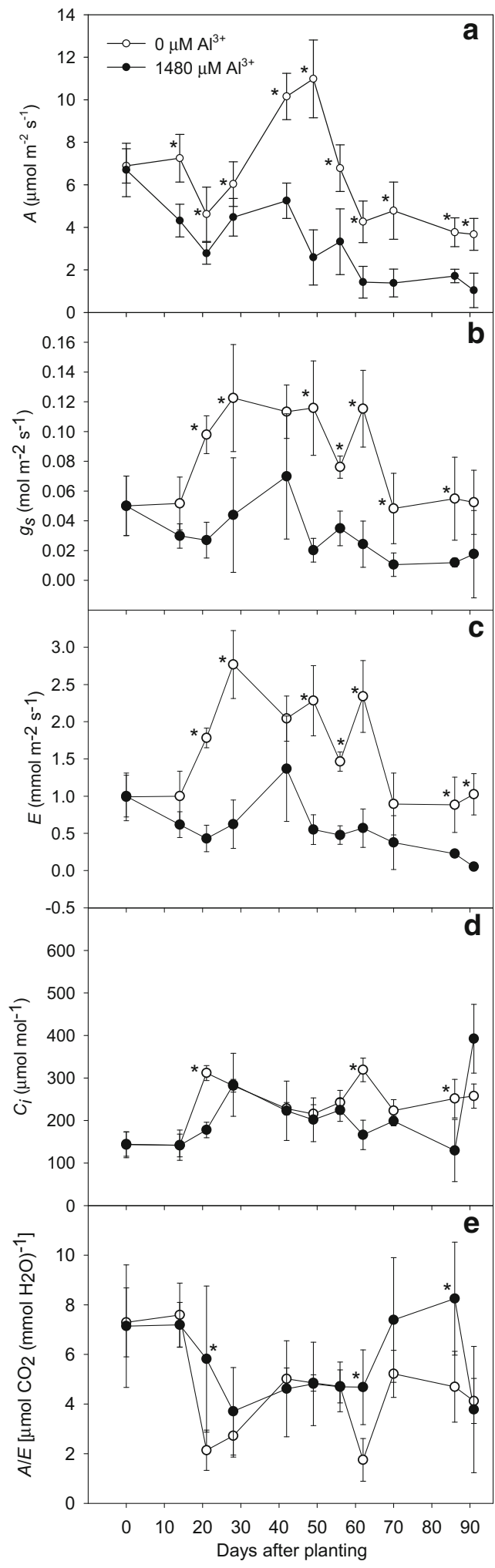




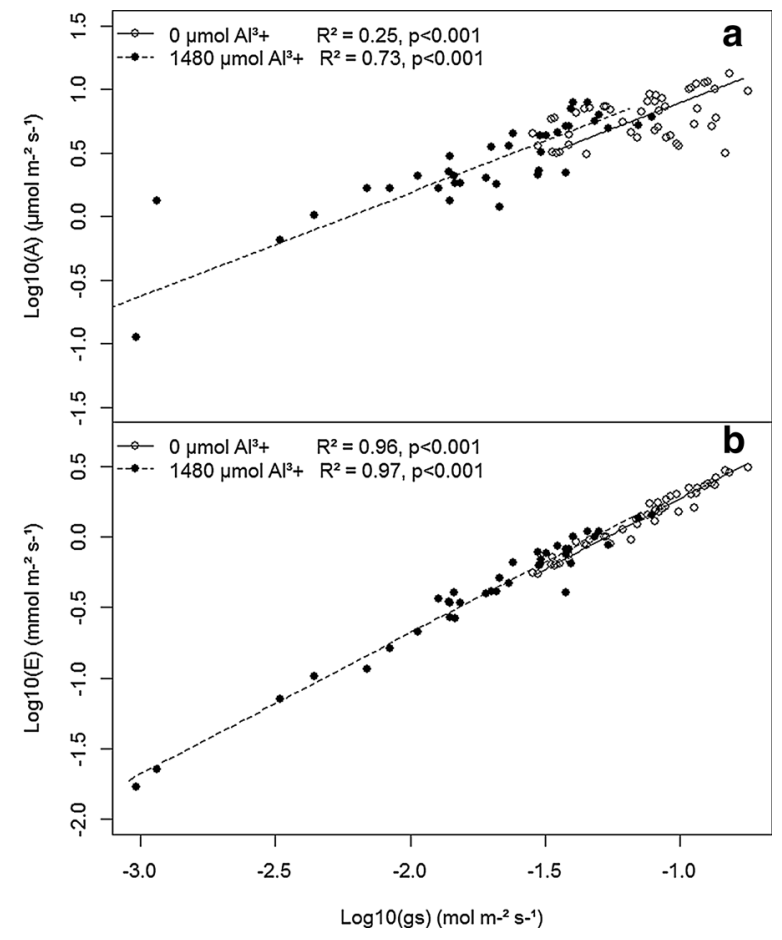

Fig. 5 Bivariate correlations between $A \times g_{s}$ (a) and $E \times g_{s}$ (b) for $S$. camporum plants grown for 91 days in nutrient solutions containing 0 and $1480 \mu \mathrm{M}$ Al. Each plot represents reading performed on one plant measured throughout the experimental time

\section{Discussion}

Differing from our prediction, the results showed that high $\mathrm{Al}$ concentration in the nutrient solution affects the growth of $S$. camporum. Although the leaves of plants exposed to Al were fully expanded and had the same shape as those from plants not exposed to $\mathrm{Al}$ (suggesting no apparent toxicity to shoots), the number of leaves of plants exposed to $\mathrm{Al}$ remained the same between 0 and 91 DAP (Fig. 2a). Therefore, the smaller leaf number (Fig. 2a), leaf area (Fig. 2b) and leaf biomass (Fig. 3a) found in plants exposed to $\mathrm{Al}$ after 91 days, in relation to plants not exposed to $\mathrm{Al}$ are likely to be due to low leaf flushing. This indicates that Al may have interfered with the functioning of the shoot apical meristem. It is difficult to find studies of $\mathrm{Al}$ effects on leaves and shoots using simple data like number of leaves, mainly in native plants from environments where $\mathrm{Al}$ is not expected to be a toxic element, although $\mathrm{Al}$ saturation is extremely high in soils from these areas (Haridasan 2008). In Cedrela

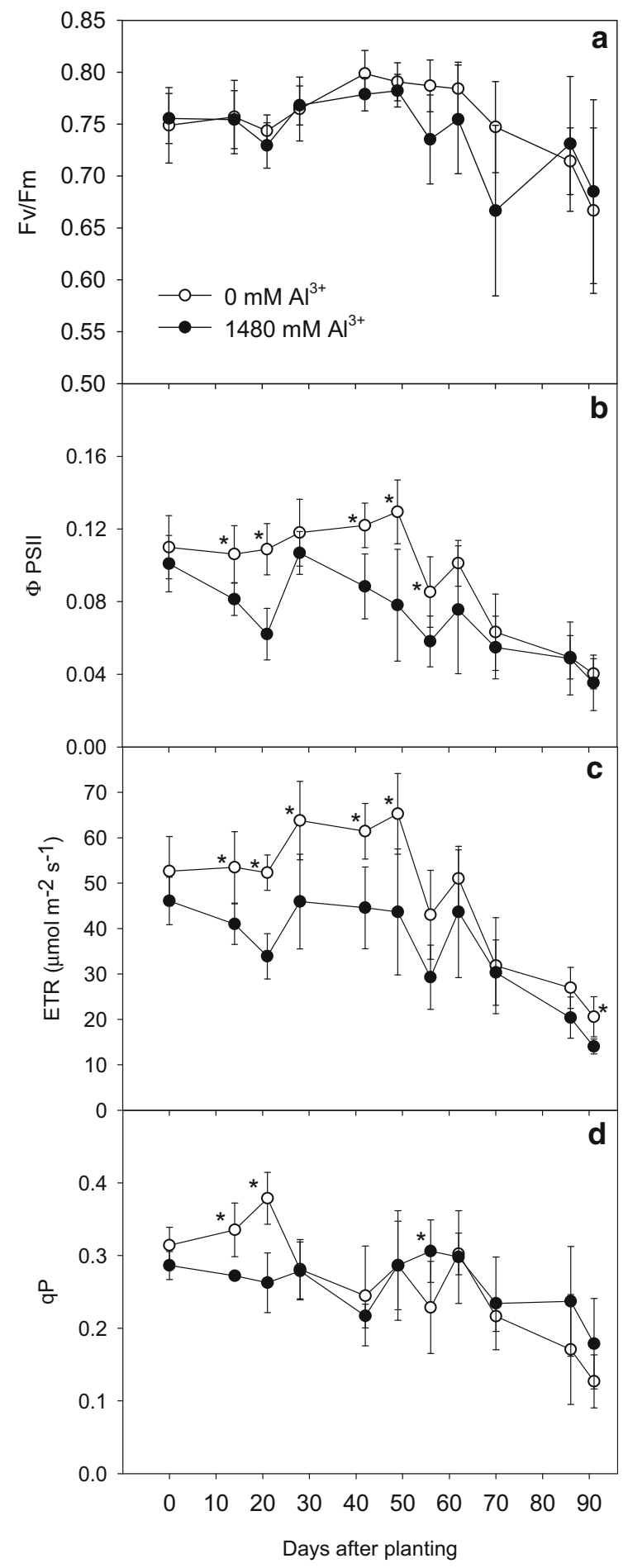

Fig. 6 Mean values ( $n=5$ plants) of chlorophyll a fluorescence parameters of $S$. camporum plants grown for 91 days in nutrient solutions containing 0 and $1480 \mu \mathrm{M}$ Al. Asterisks indicate significant difference $(\mathrm{P}<0.05)$ between treatments at each evaluation date. (vertical bars $=$ s.d.) 


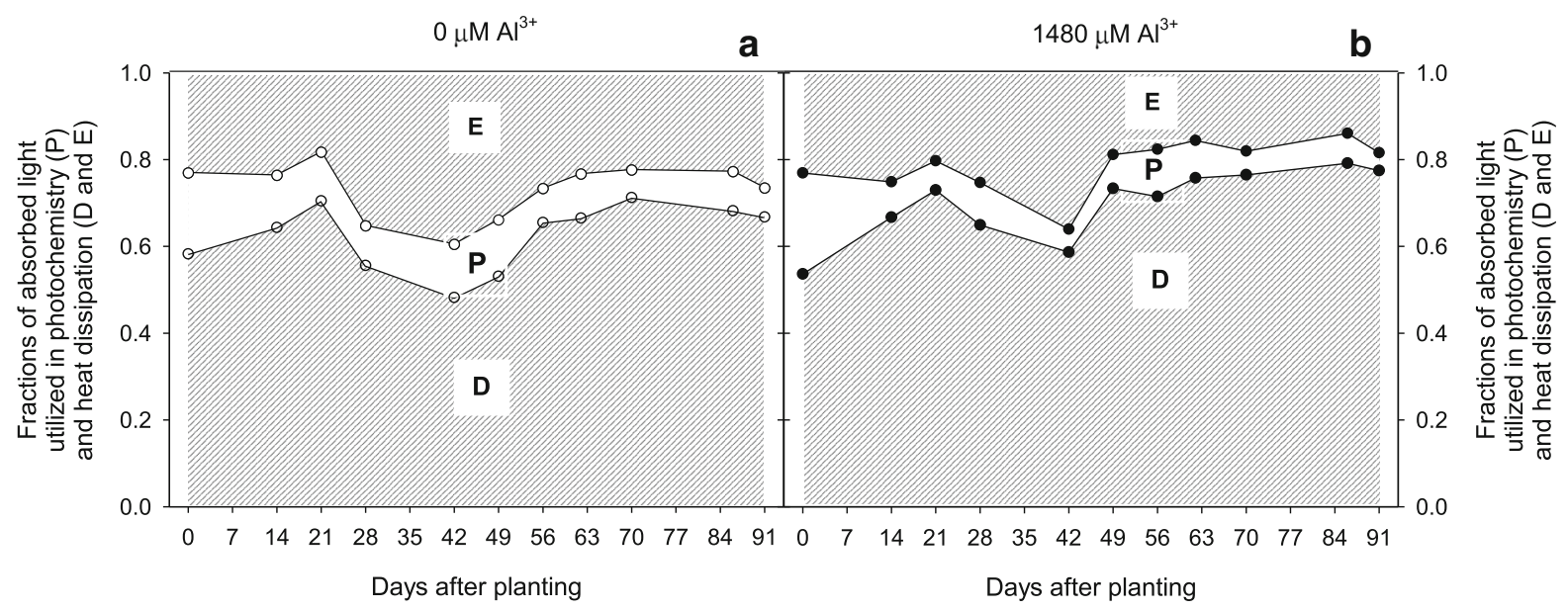

Fig. 7 Variations in fractions of absorbed light utilized in photochemistry (P), heat dissipation in the antenna (D) and in reaction centers (E) of PSII in S. camporum grown for 91 days under 0 (a) and $1480 \mu \mathrm{M} \mathrm{Al} \mathrm{(b).} \mathrm{P} \mathrm{values} \mathrm{for} \mathrm{each} \mathrm{parameter}$ between both treatments are presented below

\begin{tabular}{llllllllllll}
\hline Photochemical parameter & \multicolumn{1}{l}{ Days after planting } \\
\cline { 2 - 13 } & 0 & 14 & 21 & 28 & 42 & 49 & 56 & 62 & 70 & 86 & 91 \\
\hline E & 0.921 & 0.330 & 0.040 & 0.016 & 0.267 & 0.041 & 0.015 & 0.015 & 0.185 & 0.072 & 0.033 \\
P & 0.651 & 0.002 & 0.001 & 0.161 & 0.010 & 0.016 & 0.433 & 0.187 & 0.509 & 0.947 & 0.924 \\
D & 0.365 & 0.195 & 0.050 & 0.053 & 0.128 & 0.019 & 0.101 & 0.043 & 0.227 & 0.054 & 0.031 \\
\hline
\end{tabular}

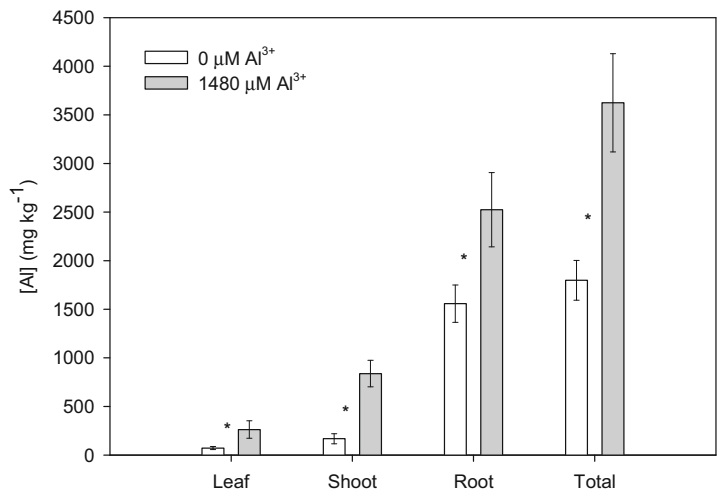

Fig. 8 Mean values ( $n=5$ plants) of $A 1$ concentration in leaves, shoots, roots, and in the whole plant of $S$. camporum grown for 91 days in nutrient solutions containing 0 and $1480 \mu \mathrm{M}$ Al. Asterisks indicate significant difference $(\mathrm{P}<0.05)$ between treatments at $91 \mathrm{DAP}($ vertical bars $=$ s.d. $)$

odorata, Heliocarpus americanus and Tabebuia chrysantha, $\mathrm{Al}$ non-accumulating species from tropical forests in Ecuador, healthy leaf area decreased and leaf chlorosis increased with the increase of $\mathrm{Al}$ concentration (Rehmus et al. 2014). In rye, an Al- sensitive species, leaves were smaller after 3 weeks under $1110 \mu \mathrm{M} \mathrm{Al}$ (Silva et al. 2012). Therefore, $S$. camporum plants demonstrate some type of resistance to $\mathrm{Al}$ because after being exposed to high $\mathrm{Al}$ concentration for 91 days leaves were green and had the same size as those from plants not exposed to Al, despite the damage to their shoot apical meristem (low leaf flushing).

Aluminum is known to cause damage to apical meristems, interfering with cell division (Matsumoto 2000), but not to shoot apical meristems. The most important symptom of Al toxicity, in general, is the inhibition of root elongation (Horst et al. 2010; Sun et al. 2010). In Al-sensitive species, low root growth can be detected within hours under $\mathrm{Al}$ concentrations as low as $10 \mu \mathrm{M}$ (Kopittke et al. 2008). In these plants, Al-induced decrease in root length may be of 60-80\% in relation to the root length of plants not exposed to $\mathrm{Al}$ (Blamey et al. 1987; Delhaize and Ryan 1995; Kopittke et al. 2008; Sun et al. 2010). In the present study, the roots of plants exposed to $\mathrm{Al}$ were only $10 \mathrm{~cm}$ shorter than those of plants not exposed to $\mathrm{Al}$ (Fig. 2d), representing a $15 \%$ reduction in the root 
length. Therefore, S. camporum exhibits some type of resistance to $\mathrm{Al}$, as the typical $\mathrm{Al}$-induced decrease in root growth exhibited by Al-sensitive species was not evidenced in this non-accumulating species from the Cerrado.

On the other hand, the most conspicuous symptom observed in the roots of $S$. camporum plants exposed to Al was the lack of lateral roots (Fig. 1d). Responsible for anchorage to the soil as well as for minerals and water supply (Kramer and Boyer 1995), lateral roots are not formed at the root meristem, but at the root maturation zone (Lavenus et al. 2013). Therefore, the root apex of $S$. camporum does not seem to be affected by $\mathrm{Al}$, contrasting with the rapid and permanent damage to root meristems of Al-sensitive species (Kopittke et al. 2008). These results suggest that the root maturation zone is somehow affected by high concentration of $\mathrm{Al}$ in this species.

We also demonstrated that $69.5 \%$ of the $\mathrm{Al}$ found in plants exposed to $\mathrm{Al}$ was retained in the roots. Aluminum was also found in plants grown in nutrient solution with no $\mathrm{Al}$ (Fig. 8), but this is a common observation in similar studies using (Al-sensitive) crop plants (Jiang et al. 2009; Yang et al. 2011). Root Al retention has already been reported for crop plants (Vitorello et al. 2005). In Citrus grandis, 70-80 \% of the $\mathrm{Al}$ was found in roots (Jiang et al. 2009; Yang et al. 2011). S. camporum is a non-accumulating plant but, as we have already observed $1000-1500 \mathrm{mg} \mathrm{Al} \mathrm{kg}^{-1}$ dry leaves in field studies, we expected to find $\mathrm{Al}$ in the leaves of plants of the present study. We did, but almost $70 \%$ of the $\mathrm{Al}$ was retained in their roots and only $7.1 \%$ in their leaves. In the field, S. camporum plants grow on soils showing $\mathrm{m} \%$ between 60 and $90 \%$ (Haridasan 2008; Andrade et al. 2011; Habermann and Bressan 2011). Although $\mathrm{m} \%$ and $\mathrm{Al}$ concentration in nutrient solutions are not comparable, it is possible that (somehow) Cerrado soils are not toxic to non-accumulating plants when compared to nutrient solution containing $\mathrm{Al}$, as demonstrated in the present study. In addition, no studies have demonstrated, so far, whether $\mathrm{Al}$ is retained (and in which proportion), or not, in the roots of S. camporum trees in the field. We did not anatomically/histochemically investigate possible sites of $\mathrm{Al}$ deposition for the $\mathrm{Al}$ we found retained in the roots of $S$. camporum plants but, apparently, the Al stunts lateral root induction in this species. This lack of lateral roots may explain the $60 \%$ lower root biomass increment between 0 and 91
DAP in plants exposed to $\mathrm{Al}$ when compared to plants not exposed to $\mathrm{Al}$ (Fig. 3c). In addition, this lack of lateral roots may have interfered with the water uptake, which could be associated with the low gas exchange rates.

Therefore, our results also suggest that the reason behind the reduced gas exchange rates in $S$. camporum plants exposed to $\mathrm{Al}$ is diffusive, i.e. dependent on early stomatal closure (Chaves 1991; Chaves et al. 2002). Carbon assimilation was reduced in plants exposed to $\mathrm{Al}$ during most of the experiment (Fig. 4a), and the low $g_{s}$ could explain their low $A$ (Fig. 5a) and $E$ (Fig. 5b) values. Thus, it seems that $\mathrm{Al}$ inhibits the formation of lateral roots at the maturation zone. Since lateral roots are responsible for water uptake (Kramer and Boyer 1995), the Alinduced decrease in lateral root formation might have caused a lack of water supply to the mesophyll, which eventually led to low $g_{s}$, and had an impact on gas exchange rates (Fig. 4a-c). Some studies (Chen et al. 2005; Jiang et al. 2008; Konrad et al. 2005; Silva et al. 2012) carried out on Al-sensitive species have reported 30-80\% decrease in $g_{s}$ in plants exposed to Al. Samac and Tesfaye (2003) and Vitorello et al. (2005) defend that, in Al-sensitive plants, Al stunts the primary root and inhibits lateral root formation, which would lead to reduced water uptake. Therefore, it is possible that a similar sequence of responses (low lateral root formation $\rightarrow$ low water uptake $\rightarrow$ low $g_{s}$ and gas exchange rates) might have occurred with $S$. camporum.

Low photochemical performances, such as reduced ETR, qP and TPSII have been observed in Alsensitive plants when exposed to this metal, which could explain the low $A$ observed in these crop plants (Chen et al. 2005; Konrad et al. 2005; Jiang et al. 2008; 2009). In the present study, low photochemical performance in plants exposed to $\mathrm{Al}$ included low ФPSII and ETR (between 14 and 56 DAP), low qP (at 14 and 21 DAP), and increased D (between 21 and 91 DAP). However, (low) $\mathrm{F}_{\mathrm{v}} / \mathrm{F}_{\mathrm{m}}$, an indicator of damage to the photochemical apparatus (Baker 2008) was unchanged between the treatments (Fig. 4a). Healthy $S$. camporum plants under water deficit (leaf water potential $=-3.2 \mathrm{MPa}$ ) also exhibit attenuation of photochemical performances (although $\mathrm{F}_{\mathrm{v}} / \mathrm{F}_{\mathrm{m}}$ is stable at $0.78 \pm 0.2$ ), and under such conditions this species has to cope with relative excessive PPFD (Feistler and Habermann 2012). Moreover, while D 
increased by 3-27.5\% in plants exposed to $\mathrm{Al}$ (Fig. 7b), $g_{s}$ values decreased by $72 \%$ (21 DAP), $64 \%$ (28 DAP), $82.5 \%$ (49 DAP), $54 \%$ (56 DAP), $78.9 \%$ (62 DAP), and $78 \%$ (at 70 and 86 DAP) in these plants (Fig. 4b). The positive relationships between $A \times g_{s}$ (Fig. 5a) and $E \times g_{s}$ (Fig. 5b) for both treatments also reinforce that $A$ was under diffusive (stomatal) control. Therefore, as observed for Al-sensitive species, in S. camporum plants the $\mathrm{Al}$ might have attenuated the photochemical performance, but the participation in such attenuation is not so important as the reduced $g_{s}$ caused by $\mathrm{Al}$ in these plants. Consequently, it is more reasonable to assume that the low photochemical performance in $S$. camporum plants exposed to Al could be a mechanism to dissipate excessive energy due to a lack of water supply to the mesophyll, which led to a significant stomatal closure.

One may still argue that most photosynthetic parameters showed a reduction after 50 DAP, and that there was a considerable variation in gas exchange and photochemical parameters throughout the experiment (Figs. 4, 6). However, these variations were similar for both treatments. In addition, from 0 to 50 DAP, the mean air temperature was $30.2 \pm 1.3{ }^{\circ} \mathrm{C}$, dropping to $27.7 \pm 1.5^{\circ} \mathrm{C}$ after 50 days. Most importantly, $A, g_{s}$ and $E$ remained higher in plants not exposed to $\mathrm{Al}$ when compared to plants exposed to $\mathrm{Al}$ (Fig. 4a-c), reiterating that gas exchange rates seemed to be largely reduced by $\mathrm{Al}$, even under variable conditions.

This may be the first report of $\mathrm{Al}$ effects on a nonaccumulating species from the Cerrado, which would not be expected to experience injuries caused by Al. Therefore, we suggest further investigation with this species, such as Al dose-response experiments. Differing from our hypothesis, high soluble Al concentration in nutrient solutions seems to affect the growth of $S$. camporum. It interferes with the shoot apex, as plants exposed to Al drastically reduced flushing. However, in contrast with Al-sensitive species, Al is not a stressful factor to the root tip, but to the root maturation zone. It seems to disturb the formation of lateral roots and, consequently, water uptake is reduced, causing a lack of water supply to the mesophyll, which would explain the low $g_{s}$ and reduced gas exchange rates.
Acknowledgments We acknowledge the São Paulo Research Foundation (Fapesp; Grant \#2012/01351-9 to GH) and the Brazilian National Council for Scientific and Technological Development (CNPq; Grant \#474169/2013-8 to GH) for the financial support. OFAA Banhos acknowledges the Coordenação de Aperfeiçoamento de Pessoal de Nível Superior (CAPES) for a $\mathrm{PhD}$ scholarship. MC Souza acknowledges FAPESP for a Postdoc fellowship (Grant \#2013/21293-6). G. Habermann acknowledges CNPq for a research productivity fellowship (Grant \#308902/2014-9).

\section{References}

Andrade LRM, Barros LMG, Echevarria GF, do Amaral LIV, Cotta MG, Rossatto DR, Haridasan M, Franco AC (2011) Al-hyperaccumulator Vochysiaceae from the Brazilian Cerrado store $\mathrm{Al}$ in their chloroplasts without apparent damage. Environ Exp Bot 70:37-42

Baker NR (2008) Chlorophyll fluorescence: a probe of photosynthesis in vivo. Annu Rev Plant Biol 59:89-113

Blamey FPC, Edwards DG, Asher CJ (1987) Nutritional disorders of sunflower. The University of Queensland, Brisbane

Bolhàr-Nordenkampf HR, Öquist GO (1993) Chlorophyll fluorescence as a tool in photosynthesis research. In: Hall DO, Scurlock JMO, Bolhàr-Nordenkampf HR, Leegood RC, Long SP (eds) Photosynthesis and production in a changing environment: a field and laboratory manual. Chapman \& Hall, London, pp 193-206

Brunner I, Sperisen C (2013) Aluminum exclusion and aluminum tolerance in woody plants. Front Plant Sci 4:1-12

Chaves MM (1991) Effects of water deficits on carbon assimilation. J Exp Bot 42:1-16

Chaves MM, Pereira JS, Maroco J, Rodrigues ML, Ricardo CPP, Osório ML, Carvalho I, Faria T, Pinheiro C (2002) How plants cope with water stress in the field. Photosynthesis and growth. Ann Bot 89:907-916

Chen L-S, Qi Y-P, Smith BR, Liu X-H (2005) Aluminum-induced decrease in $\mathrm{CO} 2$ assimilation in citrus seedlings is unaccompanied by decreased activities of key enzymes involved in $\mathrm{CO}_{2}$ assimilation. Tree Physiol 25:317-324

Clark RB (1975) Characterization of phosphatase of intact maize roots. J Agric Food Chem 23:458-460

Delhaize E, Ryan PR (1995) Aluminum toxicity and tolerance in plants. Plant Physiol 107:315-321

Demming-Adams B (1996) Using chlorophyll fluorescence to assess the fraction of absorbed light allocated to thermal dissipation of excess excitation. Physiol Plant 98:253-264

Feistler AM, Habermann G (2012) Assessing the role of vertical leaves within the photosynthetic function of Styrax camporum under drought conditions. Photosynth 50:613-622

Furlani AMC, Furlani PR (1988) Composição e pH de soluções nutritivas para estudos fisiológicos e seleção de plantas em condições adversas. IAC, Campinas (Boletim Técnico, 121). [In Portuguese]

Habermann G, Bressan ACG (2011) Root, shoot and leaf traits of the congeneric Styrax species may explain their 
distribution patterns in the Cerrado sensu lato areas in Brazil. Funct Plant Biol 38:209-218

Habermann G, Machado EC, Rodrigues JD, Medina CL (2003) Gas exchange rates at different vapor pressure deficits and water relations of 'Pera' sweet orange plants with citrus variegated chlorosis (CVC). Sci Hortic 98:233-245

Habermann G, Ellsworth PFV, Cazoto JL, Feistler AM, Silva L, Donatti DA, Machado SR (2011) Leaf paraheliotropism in Styrax camporum confers increased light use efficiency and advantageous photosynthetic responses rather than photoprotection. Environ and Exp Bot 71:10-17

Haridasan M (1982) Aluminium accumulation by some cerrado native species of central Brazil. Plant Soil 65:265-273

Haridasan M (2008) Nutritional adaptations of native plants of the cerrado biome in acid soils. Braz J Plant Physiol 20:183-195

Haridasan M, Araujo GM (1988) Aluminium-accumulating species in two forest communities in the cerrado region of central Brazil. For Ecol Manage 24:15-26

Horst WJ, Wang Y, Eticha D (2010) The role of the root apoplast in aluminium-induced inhibition of root elongation and in aluminium resistance of plants: a review. Ann Bot 106:187-197

Jiang H-X, Chen L-S, Zheng J-G, Han S, Tang N, Smith BR (2008) Aluminum-induced effects on photosystem II photochemistry in Citrus leaves assessed by the chlorophyll a fluorescence transient. Tree Physiol 28:1863-1871

Jiang H-X, Tang N, Zheng J-G, Li Y, Chen L-S (2009) Phosphorous alleviates aluminum-induced inhibition of growth and photosynthesis in Citrus grandis seedlings. Physiol Plant 137:298-311

Kissmann C, Habermann G (2013) Seed germination performances of Styrax species help understand their distribution in Cerrado areas in Brazil. Bragantia 72:199-207

Kissmann C, Tozzi HH, Martins S, Habermann G (2012) Germination performance of congeneric Styrax species from the Cerrado sensu lato areas and their distribution pattern in different physiognomies. Flora 207:673-681

Konrad MLF, Silva JAB, Furlani PR, Machado EC (2005) Gas exchange and chlorophyll fluorescence in six coffee cultivars under aluminum stress. Bragantia 64:339-347

Kopittke PM, Blamey FPC, Menzies NW (2008) Toxicities of $\mathrm{Al}, \mathrm{Cu}$, and $\mathrm{La}$ include ruptures to rhizodermal and root cortical cells of cowpea. Plant Soil 303:217-227

Kopittke PM, Blamey FPC, Asher CJ, Menzies NW (2010) Trace metal phytotoxicity in solution culture: a review. J Exp Bot 61:945-954

Kramer PJ, Boyer JS (1995) Roots and root systems. In: Kramer PJ (ed) Water relations of plants and soils. Academic Press, San Diego, pp 115-166

Lavenus J, Goh T, Roberts I, Guyomarc'h S, Lucas M, De Smet I, Fukaki H, Beeckman T, Bennett M, Laplaze L (2013) Lateral root development in Arabidopsis: fifty shades of auxin. Trends Plant Sci 18:450-458

Matsumoto H (2000) Cell biology of aluminum toxicity and tolerance in higher plants. Intern Rev Citol 200:1-46

Nakajima JN, Monteiro R (1987) Padrões de distribuição especial de espécies de Styrax (Styracaceae) de cerrados. Arq Biol Tecnol 30:419-430 [in Portuguese]

Pivello VR, Oliveras I, Miranda HS, Haridasan M, Sato MN, Meirelles ST (2010) Effect of fires on soil nutrient availability in an open savanna in Central Brazil. Plant Soil 337:111-123
Rangel AF, Rao IM, Horst WJ (2009) Intracellular distributing and biding state of aluminum in root apices of two common bean (Phaseolus vulgaris) genotypes in relation to $\mathrm{Al}$ toxicity. Physiol Plant 135:162-173

Ratter JA, Ribeiro JF, Bridgewater S (1997) The Brazilian Cerrado vegetation and threats to its biodiversity. Ann Bot 80:223-230

R Development Core Team (2012) R: a language and environment for statistical computing. $\mathrm{R}$ foundation for statistical computing, Vienna, http://www.r-project.org

Rehmus A, Bigalke M, Valarezo C, Castillo JM, Wilcke W (2014) Aluminum toxicity to tropical montane forest tree seedlings in southern Ecuador: response of biomass and plant morphology to elevated Al concentrations. Plant Soil 382:301-315

Samac DA, Tesfaye M (2003) Plant improvement for tolerance to aluminum in acid soils-a review. Plant Cell Tiss Org Cult 75:189-207

Santos CH, Grassi Filho H, Rodrigues JD, Pinho SZ (2000) Influence of different levels of aluminum on the development of citrus rootstock 'Swingle' citrumelo (Citrus paradisi mcf. x Poncirus trifoliata Raf.) in nutrient solution. Braz Arch Biol Tech. doi:10.1590/S1516-89132000000 100004

Sarruge JR, Haag HP (1974) Análises Químicas em Plantas. Escola Superior de Agricultura Luiz de Queiróz, Piracicaba [In Portuguese]

Scalon MC, Haridasan M, Franco AC (2013) A comparative study of aluminium and nutrient concentrations in mistletoes on aluminium-accumulating and non-accumulating hosts. Plant Biol 15:851-885

Shaff JE, Shultz BA, Craft EJ, Clark RT, Kochian LV (2010) GEOCHEM-EZ: a chemical speciation program with greater power and flexibility. Plant Soil 330:207-214

Silva S, Pinto G, Dias MC, Correia CM, Moutinho-Pereira J, Pinto-Carnide O, Santos C (2012) Aluminium long-term stress differently affects photosynthesis in rye genotypes. Plant Physiol Biochem 54:105-112

Souza MC, Bueno PCP, Morellato LPC, Habermann G (2015a) Ecological strategies of Al-accumulating and non-accumulating functional groups from the cerrado sensu stricto. Ann Acad Bras Ciên 87:813-823

Souza MC, Franco AC, Haridasan M, Rossatto DR, Araújo JF, Morellato LPC, Habermann G (2015b) The length of the dry season may be associated with leaf scleromorphism in cerrado plants. Ann Acad Bras Ciên 87:1691-1699

Sun P, Tian Q-Y, Chen J, Zhang W-H (2010) Aluminium-induced inhibition of root elongation in Arabidopsis is mediated by ethylene and auxin. J Exp Bot 61:347-356

Vitorello VA, Capaldi FR, Stefanuto VA (2005) Recent advances in aluminum toxicity and resistance in higher plants. Braz J Plant Physiol 17:129-143

Warton DI, Wright IJ, Falster DS, Westoby M (2006) Bivariate line-fitting methods for allometry. Biol Rev 81:259-291

Warton DI, Duursma RA, Falster DS, Taskinen S (2012) SMATR 3 - an R package for estimation and inference about allometric lines. Methods Ecol Evol 3:257-259

Yang L-T, Jiang H-X, Tang N, Chen L-S (2011) Mechanisms of aluminum-tolerance in two species of citrus: secretion of organic acid anions and immobilization of aluminum by phosphorous in roots. Plant Sci 180:521-530 